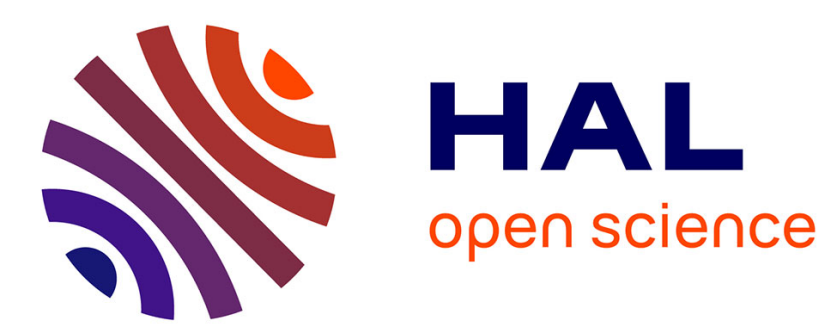

\title{
TEMPERATURE DEPENDENCE OF IRIDIUM FIELD EVAPORATION RATE
}

\author{
A. Menand, D. Blavette
}

\section{To cite this version:}

A. Menand, D. Blavette. TEMPERATURE DEPENDENCE OF IRIDIUM FIELD EVAPORATION RATE. Journal de Physique Colloques, 1986, 47 (C7), pp.C7-17-C7-20. 10.1051/jphyscol:1986704 . jpa-00225893

\section{HAL Id: jpa-00225893 https://hal.science/jpa-00225893}

Submitted on 1 Jan 1986

HAL is a multi-disciplinary open access archive for the deposit and dissemination of scientific research documents, whether they are published or not. The documents may come from teaching and research institutions in France or abroad, or from public or private research centers.
L'archive ouverte pluridisciplinaire HAL, est destinée au dépôt et à la diffusion de documents scientifiques de niveau recherche, publiés ou non, émanant des établissements d'enseignement et de recherche français ou étrangers, des laboratoires publics ou privés. 
TEMPERATURE DEPENDENCE OF IRIDIUM FIELD EVAPORATION RATE

\author{
A. MENAND and D. BLAVETTE \\ U.A. CNRS, Laboratoire de Mícroscopie Ionique, Faculté des \\ Sciences de Rouen, $B P$ 67, F-76130 Mont-Saint-Aignan, France
}

\begin{abstract}
Résumé - Différents auteurs ont suggéré 1a possibilité d'un effet tunnel ioni-

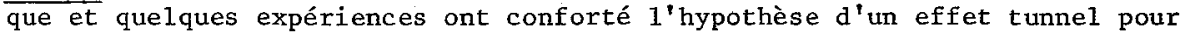
les ions $W$ ou $B$ à basse température.

Nous avons déterminé, par Microscopie ionique, 1a dépendance en température du flux d'ions évaporés par effet de champ (en plans évaporés par seconde). Les résultats montrent đeux régimes différents à haute et basse températures, 1a température de transition étant comprise entre 35 et $40 \mathrm{~K}$. A basse température le flux est beaucoup moins dépendant de la température. Ceci est interprété comme le résultat d'une désorbtion des ions iridium par un mécanisme d'effet tunne1 en dessous de $35 \mathrm{~K}$.
\end{abstract}

\begin{abstract}
The possibility of ionic tunneling has been suggested previously by several authors, and some experiments have been already reported giving indication for the quantum mechanical tunneling of $W$ or $B$ ions at low temperatures.

We performed FIM experiments on Iridium to determine the temperature dependence of the relative field evaporation rate (in layers per second). The results show two different regimes at high and low temperatures, with a transition temperature between $35 \mathrm{~K}$ and $40 \mathrm{~K}$. The much more smaller temperature dependence at low temperature is interpreted as being indicative of a tunneling mechanism of field desorption of Iridium ions below $35 \mathrm{~K}$.
\end{abstract}

\title{
I - INTRODUCTION
}

The quantum mechanical phenomenon of tunneling has been known for more than 50 years. Among the best examples of tunneling are $\alpha$ particle decay of nuclei $/ 1 /$ and field emission of electron /2/. More recently the existence of a molecular tunneling has been reported for chemical reactions $/ 3 /$.

The possibility that field desorption at low temperature would be the result of ionic tunneling has been suggested previously $/ 4 /, / 5 /, 16 /, / 7 /, / 8 /, / 9 /, / 10 /$. We have: recently reported some experimental evidences showing that boron ions are field desorbed by ionic tunneling up to a temperature of $140 \mathrm{~K} / 11 /$.

At high temperature the field desorption of atoms is a full thermally activated process while at very low temperature the desorption reduces to pure tunneling.

Between these two situations a transition temperature $T_{c}$ exists, defined by the equality of the two desorption rate constants.

In this paper we present a FIM study of the temperature dependence of desorption rate for iridium at low temperature where tunneling is supposed to occur. 


\section{II - EXPERTMENTAL}

We measured the desorbtion rate constant of iridium using a ring counting technique $/ 12 /$. The desorption rates were obtained in layers per second.

The specimen was cooled down to $20 \mathrm{~K}$ using a close-circle cryogenerator. The temperature could be adjusted by heating the cryotip by means of electrical resistances. The temperature was measured at the base of the sample holder with a Fe Au-chromel Thermocouple with a reference at $77 \mathrm{~K}$. The difference between the actual tip temperature and the measured one's has been estimated to be close to $10 \mathrm{~K}$. The experimental protocole is as follows : the applied potentiel $V_{D C}$ is first settled to a choosen value. Then the time required to evaporate one (or severa1) layer is measured. The potential is then decreased and afterwards the tip temperature is changed and stabilized before a new measurement.

Since the barrier height and width are field dependent it is necessary to hold the field constant during the whole measurements. Because the tip radius generally increase during the experiments it is necessary to compensate this phenomenon by increasing the applied voltage.

This can be achieved in a simple way since for a constant field there is a linear relationship between this potentiel increase $v_{1}-V_{2}$ which is required and the number of evaporated planes $n / 13 /$. When the pole of interest is located at the tip axis :

with

$$
\begin{aligned}
& \mathrm{V}_{1}-\mathrm{V}_{2}=\mathrm{n} \Delta \mathrm{V}(\mathrm{hk} 1) \\
& \Delta \mathrm{V}(\mathrm{hk} 1)=\frac{\mathrm{E} \beta \mathrm{a}}{\sqrt{\mathrm{h}^{2}+\mathrm{k}^{2}+1^{2}}} \times \frac{\sin \alpha / 2}{1-\sin \alpha / 2}
\end{aligned}
$$

where $\alpha$ is the cone angle of the tip, a the lattice parameter, $E$ the applied field and $\beta$ the field proportionality factor defined by $E=V / B R$ with $R$ the tip radius.

The value of $\Delta V$ (hkl) can be accuratly determined with a preliminary experiment. As the applied voltage is slowly increased the number of field evaporated planes is recorded. The figure 1 shows the results obtained for two different tips. The number $\mathrm{n}$ of field evaporated planes is plotted versus the applied voltage $V$. The linear relationship between $\mathrm{n}$ and $\mathrm{V}$ is well verified. The cone angles calculated from these data are respectively equal to $4.5^{\circ}$ and $8.8^{\circ}$. As mentionned by $D$. Blavette $/ 13 /$ the $\Delta V$ (hk1) parameter is only dependent upon the cone angle and the cristallographic plane, it does not depend on the increase voltage rate.

\section{III - RESULTS AND DISCUSSION}

The figure 2 gives the results obtained for three different applied field strengths . The logarithms of evaporation rates (measured in layer per second) are plotted versus $1 / T$.

For the first experiment conducted at the lower field we did not succeed to go down in temperature below $58 \mathrm{~K}$ because the time required to evaporate one layer was yet greater than half an hour. For this experiment points are alined on a straight line corresponding to an activation energy $Q_{n}=0.106 \mathrm{eV}$.

The experiments 2 and 3 were performed at higher fields (for instance the increase in field is about $6 \%$ between experiment 1 and 2). A sharp change in the slope occurs within $35-40 \mathrm{~K}$. Two distincts regimes can be readily observed : above $40 \mathrm{~K}$ and below $40 \mathrm{~K}$.

Severa1 explanations have to be considered in the interpretation of such a change in the evaporation rates. Wada /14/ suggested the possibility of two differents thermally activated processes : migration of an atom from a site to another prior evaporation. At low temperature below $\mathrm{T}_{c}$ the observed desorbtion rate would be controlled by the migration rate while above $T_{c}$ the evaporation process would become rate-controlling.

However we think that the activation energy which is observed at low temperature is so small $\left(Q_{n} \sim 10^{-3} \mathrm{eV}\right)$ that a tunneling effect is more likely. 

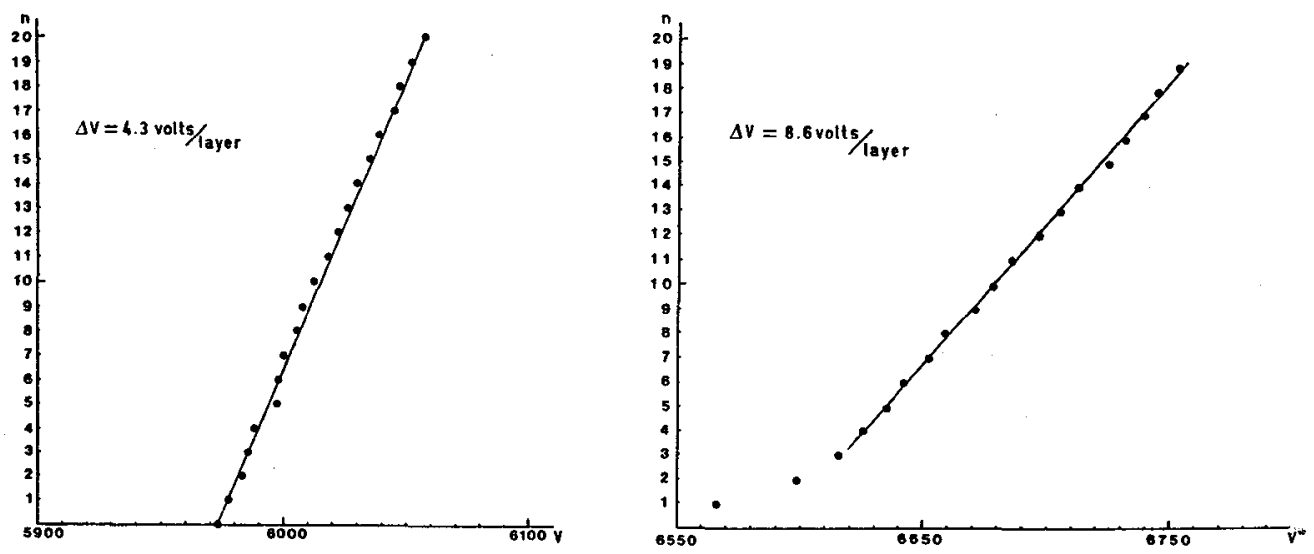

Figure 1 - Number of field evaporated planes as a function of the applied voltage for two different tips.

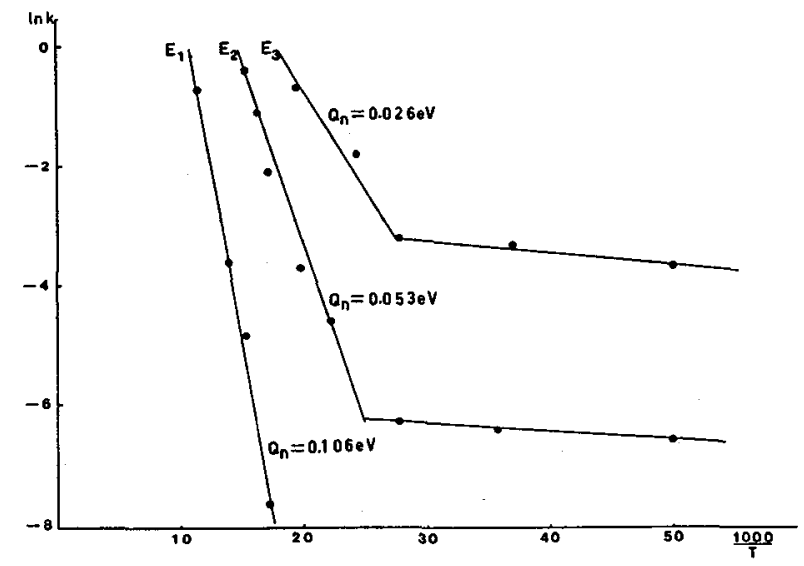

Figure 2 - Arrhenius plots for the field evaporation of iridium, for three increasing values $E_{1}, E_{2}, E_{3}$ of the applied field. 
Tsong /7/ and Kingham /10/ estimates give a critical temperature $\mathrm{T}_{\mathrm{c}}$ lying between $50 \mathrm{~K}$ and $75 \mathrm{~K}$ for iridium and for a barrier height and width respectively equal to $0.1 \mathrm{eV}$ and $0.1 \AA$.

Considering a parabolic shape for the barrier

$$
\mathrm{T}_{\mathrm{c}}=\frac{\not / \sqrt{2}}{\pi \mathrm{k}_{\mathrm{B}}}\left(\frac{\mathrm{Q}_{\mathrm{n}}}{\mathrm{M}}\right)^{\mathrm{I} / 2} \mathrm{~L}^{-1}
$$

when $Q$ and $L$ are the barrier height and width and $M$ the ion mass. If we take as true the barrier heights observed above $T$ for thermal activated desorption, the critical temperature $35-40 \mathrm{~K}$ is consistent with barrier widths of 0.1 and $0.13 \AA$ for respectively $Q_{n}=0.053$ and $0.026 \mathrm{eV}$.

of course these experiments were performed with the presence of imaging gaz. Kellogg /15/ pointed out that the influence of gaz upon activation energy was significant even at a low background pressure of $5 \times 10^{-10}$ Torr. This probably explains the low activation energies observed above $\mathrm{T}_{c}$ compared to Kellog results.

\section{REFERENCES}

11/ Gamov, G. Z., Z. Physik 51, 204 (1928)

$12 /$ Fowler, R. H. and Nordheim, Proc. Roy. Soc. A119 (1928)

/3/ Goldanskii, V. I., Nature 279, 109 (1979)

$14 /$ Gomer, R. and Swanson, L. W., J. Chem. Phys. 38, 1613 (1963)

15/ Brandon, D. G., Phil. Mag. 14, 803 (1966)

/6/ Ehrlich, G. and Kirk, C. F., J. Chem. Phys. 48, 1465 (1967)

/7/ Tsong, T. T., Surf. Sci. 10, 102 (1968)

18/ Wada, M., Konishi, M. and Nishikawa, 0., Surf. Sci. 100, 439 (1980)

19/ Chibane, K., Forbes, R. G., Surf. Sci.122, 191 (1982)

/10/ Kingham, D. R., Surf. Sci.116, 273 (1982)

/11/ Menand, A. and Kingham, D. R., J. Phys. C 18, 4539 (1985)

$/ 12$ / Tsong, T. T. and Müller, E. W., Phys. Stat. Sol. (a) 1, 513 (1970)

/13/ Blavette, D., Bostel, A., Sarrau, J. M. and Gallot, J., Proc. 29th IFES, 497, Almqvist and Wiksel1, Stockholm

/14/ Wada, M., Surf. Sci. 145, 451 (1984)

/15/ Kellogg, G. L., Phys. Rev. B 29, 4304 (1984) 